Prekaryjna praca kwestia społeczną?, red. J. Mazur OSPPE, Kraków 2018, s. 43-57.

DOI: http://dx.doi.org/10.15633/9788347386609.04

\title{
Katarzyna Zamorska
}

Uniwersytet Wroctawski

\section{PROBLEM PREKARYJNEJ PRACY - PERSPEKTYWA POLITYKI SPOŁECZNEJ}

\section{Wstęp}

Termin prekariat ${ }^{1}$ używany jest $\mathrm{w}$ socjologii co najmniej od lat 80. ubiegłego wieku na określenie charakterystycznej sytuacji pracowników tymczasowych i sezonowych. Zarówno wtedy, jak i obecnie oznacza niepewne położenie osób zatrudnionych na rynku pracy. Niepewność ta jest wynikiem nie tyle samego bezrobocia, które oczywiście - zwłaszcza wysokie - sprzyja poczuciu braku bezpieczeństwa socjalnego i społecznego, co zmian, jakie w drugiej połowie XX wieku zaczęły stopniowo zachodzić w świecie pracy. Ich specyfika sprowadza się do zastąpienia tradycyjnych umów o pracę rozmaitymi atypowymi formami, które po pierwsze nie gwarantują regularnych dochodów, a tym samym ich nie zabezpieczają. Po drugie, pozbawiają częściowo lub całkowicie ochrony przed zagrożeniami społecznymi, które są konsekwencją bezrobocia, choroby czy starości. W następnej kolejności - ograniczają częściowo lub całkowicie prawa pracownicze, by na końcu doprowadzić do zaniku tożsamości zawodowej.

${ }^{1}$ Jest to neologizm, powstały z połączenia dwóch słów: precarious (niepewny) i proletariat (biedna klasa pracująca). 
Pewność pracy, do której przywiązane było przede wszystkim powojenne pokolenie, nie jest już zatem dziś tak oczywista. W tym właśnie sensie należy rozumieć głoszone, zwłaszcza w ostatniej dekadzie XX wieku, hasło o „końcu pracy”2. Rzecznikiem tej idei był, między innymi, Jeremy Riffkin. Chodziło rzecz jasna o pracę, jaką znamy, czyli pełnoetatową, z obowiązka$\mathrm{mi}$, ale i licznymi gwarancjami pracowniczymi. Zatrudnienie niepracownicze oznacza bowiem, że pracownik wykonuje co prawda tę samą pracę, ale $\mathrm{w}$ zupełnie innych warunkach: przestaje być chroniony, nie podlega szkoleniom tak jak pracownicy zatrudnieni w firmie na stałe etc.

Dodatkowym skutkiem zachodzących zmian było i jest poszerzanie się obszarów ubóstwa. Nawet jeśli nie teraz, to w przyszłości, kiedy liczni obecni prekariusze osiągną wiek emerytalny i nie będą $\mathrm{w}$ stanie zapewnić sobie egzystencji, stając się z konieczności w większości przypadków klientami różnych instytucji pomocowych.

Praca, bezpieczeństwo, ubóstwo są to - jak wiemy ze studiów - zagadnienia, które od samego początku określały istotę polityki społecznej, rozumianej zarówno jako teoria naukowa, jak i praktyczna działalność państwa i jego podmiotów.

Ponieważ zarysowane tu istotne zmiany, jakie można zaobserwować w związku z pracą, już się dokonały, pozostaje w nawiązaniu do tytułu zastanowić się nad rolą polityki społecznej, i jeśli nie w kreowaniu prekarnych miejsc pracy, to co najmniej w niedostatecznej reakcji na zjawisko. Inny problem zawiera się w pytaniu, czy i w jaki sposób w zaistniałej sytuacji polityka społeczna może urzeczywistniać jedną ze swoich podstawowych wartości, jaką jest zaspokajanie potrzeb obywateli? Potrzeba ta realizowana jest wła-

${ }^{2}$ Jeremy Riffkin opisał to w książce Koniec pracy. Schyłek sity roboczej na świecie i początek ery postrynkowej (Wydawnictwo Dolnośląskie, Wrocław 1998). Jest to zresztą tylko jeden z wielu "końców”, jakie głoszono pod koniec XX wieku. Można jeszcze, tytułem przykładu, wymienić choćby koniec historii i ideologii (Francis Fukuyama), koniec druku i słowa pisanego, państwa narodowego czy rodziny (nuklearnej). 
śnie przede wszystkim przez gwarancje bezpieczeństwa społecznego, dobrobyt, zdrowie, godność i możliwość samospełnienia się w życiu. Niepewność związana z atypowymi formami zatrudnienia ma bowiem wpływ na wszystkie dziedziny życia.

Zadaniem, jakie zatem stawiam sobie w prezentowanym tekście, jest rozważenie prekaryzacji pracy z punktu widzenia polityki społecznej. W tym celu należy uchwycić całą złożoność zagadnienia przez zaprezentowanie konceptualizacji prekariatu, następnie odniesienie się do zjawiska prekaryzacji pracy, by na koniec przyjrzeć się możliwej reakcji polityki społecznej na nasilający się problem.

\section{Konceptualizacja prekariatu}

Dyskusje na temat prekariatu z uwzględnieniem wszelkich jego odmian, takich jak prekariusz, prakaryzacja czy prekarna praca, toczyły się do tej pory głównie w społeczeństwach zachodnich. Zmiany na rynku pracy, których doświadczamy obecnie także w Polsce, tam przecież najpierw się dokonywały. Diagnoza zmierzchu pewnego porządku społecznego, ukształtowanego i opartego o swoisty "przymus”, nadała tym dyskusjom pewien kształt. Wspomniany tu już Jeremy Riffkin pisał, że „w ciągu niecałego stulecia można się spodziewać topnienia masowego zatrudnienia w sektorze rynkowym praktycznie we wszystkich uprzemysłowionych państwach świata. (...) inteligentne maszyny zastępują człowieka w niezliczonych zajęciach, skazując miliony pracowników umysłowych i fizycznych na kolejkę po zasiłek dla bezrobotnych lub nawet po darmowe posiłki"3. Wątek ten podjęli także, przykładowo, Hans-Peter Martin i Harald Schumann, redukując przyszłość do pojęcia „20:80”. „W nadchodzącym stuleciu - prorokowali - wy-

${ }^{3}$ J. Riffkin, Schyłek siły roboczej na świecie i początek ery postrynkowej, tłum. E. Kania, Wrocław 2003, s. 17. 
starczy 20 procent zdolnej do pracy populacji, aby utrzymać światową gospodarkę $\mathrm{w}$ jej rozmachu"4. Istotę problemu stanowiło więc to, że wzrost gospodarczy i zapowiadana obfitość nie przekładają się na możliwość zharmonizowania potrzeb i oczekiwań jednostek lub grup z funkcjami pełnionymi w systemie. Może wydawać się, że diagnozy te doprowadzone zostały do stanu krytycznego, jednak wyraźnie ukazywały nadchodzące tendencje.

Powróćmy do terminu prekariat. W latach 90. XX wieku socjolog francuski Pierre Bourdie, który zajmował się tym zagadnieniem, na podstawie badań doszedł do wniosku, że jest to zjawisko o charakterze powszechnym i jest spowodowane przede wszystkim uelastycznieniem rynku pracy. Uelastycznienie polegało na tworzeniu nietypowych i jednocześnie niestabilnych form zatrudnienia na czas określony, w niepełnym wymiarze czasu pracy. Mieszczą się tu między innymi wszelkie umowy o dzieło, zlecenia itp. ${ }^{5}$ To, co miało być rozwiązaniem, a przynajmniej ograniczeniem bezrobocia w warunkach globalnej gospodarki, w krótkim czasie zaczęło sprzyjać pojawieniu się prekariatu i wszystkiego, co jest z nim związane.

Prekariat stał się także centralnym zagadnieniem rozważanym przez innego francuskiego socjologa - Roberta Castela. Warstwa ludzi pozbawiona perspektyw na stałą pracę i wynikających z niej uprawnień nie jest co prawda niczym nowym, ale Castel przeanalizował zmiany, jakim poddawana była rola pracownika najemnego od XIX wieku do czasów współczesnych ${ }^{6}$. Opisał proces, który przebiegał stopniowo i polegał na wprowadzaniu przepisów, które regulowały zawieranie umów o pracę

${ }^{4}$ H.-P. Martin, H. Schumann, Pułapka globalizacji. Atak na demokracje i dobrobyt, tłum. M. Zubyra, Wrocław 1999, s. 8.

${ }^{5}$ P. Bourdieu, Prekarität ist überall, w: Gegenfeuer. Wortmeldungen im Dienste des Widerstandes gegen die neoliberale Invasion, hrsg. A. Pfeuffer, UVK, Konstanz 1998, s. 96-102.

${ }^{6}$ Zagadnieniu temu poświęcona została książka R. Castela, Die Metamorphosen der sozialen Frage. Eine Chronik der Lohnarbeit, UVK Verlagsgesellschaft mbH, Konstanz 2000. 
i jednocześnie zaczęły systematycznie ochraniać najpierw samego pracownika, a później także członków rodziny. Dzięki temu pracownik zyskał pewną godność, choć - rzecz jasna - nie udało się ostatecznie zlikwidować ekonomicznego wyzysku. W czasach powojennej gospodarczej prosperity w krajach Europy Zachodniej, zwłaszcza w okresie, który przeszedł do historii jako trzydzieści wspaniałych lat (1945-1975), dokonał się rozwój systemu świadczeń społecznych i usług publicznych dostępnych dla wszystkich, wzrost płac robotniczych i urzędniczych oraz wykształciły się średnie warstwy społeczne. Jednak począwszy od lat 90. XX wieku neoliberalne przemiany na rynku pracy wykreowały sytuację, w której stabilizacja i spójność społeczna stała się luksusem dla nielicznych. Castel i Klaus Dörre postawili nawet tezę, zgodnie z którą społeczna niepewność, towarzysząca pracy, świadczy o tym, że wielka kwestia pracy powróciła u progu XXI wieku7. Kwestia pracy zaś jako kwestia społeczna jest przypisana do polityki społecznej, stąd jej ogromne znaczenie jako zagadnienia, które rozpatruje się zarówno na poziomie teorii, jak i w wymiarze praktycznym.

Sytuację "pracowników sezonowych", "tymczasowych", "pracujących ubogich”, "nadliczbowych” czy "ludzi zbędnych” analizował także wielokrotnie Zygmunt Bauman. Najdobitniej problem został przedstawiony w książce Życie na przemiał, w której autor dowodził, że płynna nowoczesność to „cywilizcja nadmiaru, zbędności, odpadów i konieczności ich uprzątania” 8 . Co więcej, „w tych warunkach żadna granica oddzielająca »odpady« od »użytecznego produktu « nie może być ostateczna"9. Oznacza to, że linia ta zaciera się i traci wyrazistość. Każdy może znaleźć się nagle po niewłaściwej stronie.

${ }^{7}$ R. Castel, K. Dörre (Hrsg.), Prekarität, Abstieg, Ausgrenzung. Die soziale Frage am Beginn des 21. Jahrhunderts. Campus, Frankfurt am Main / New York 2009, s. 11-18.

${ }^{8}$ Z. Bauman, Życie na przemiał, tłum. T. Kunz, Kraków 2004, s. 153.

${ }^{9}$ Z. Bauman, Życie na przemiat, dz. cyt., s. 139. 
Z kolei Ulrich Beck wprowadził termin spoteczeństwa ryzy$k a$, w którym nowoczesne społeczeństwo narażone jest na niebezpieczeństwa nieokreślonego rodzaju, które powodują życie w niepewności i ciągłym strachu, także przed utratą pracy albo w ogóle brakiem możliwości wejścia na rynek pracy ${ }^{10}$. Zawsze zatem - powtórzmy - istnieli ludzie, którzy nie mieli pewności co do trwałości wykonywanej przez nich pracy, jednak rolą polityki społecznej było łagodzenie przynajmniej najbardziej skrajnie negatywnych przejawów funkcjonowania rynku.

W Polsce największy rozgłos koncepcja prekariatu zyskała jednak za sprawą Gaya Standinga. Na jego książkę z 2011 roku Prekariat. Nowa niebezpieczna klasa powołują się obecnie nie tylko przedstawiciele świata nauki, ale także dziennikarze, co zapewne przyczyniło się do szybszego oswojenia się i przyswojenia przez czytelników nie tylko z kręgów nauki z samym terminem.

\section{Co oznacza przynależeć do prekariatu?}

Czy prekariusz to współczesny odpowiednik proletariusza? Aby odpowiedzieć na to pytanie, należy przyjrzeć się poszczególnym grupom, jakie funkcjonują na rynku pracy.

Klaus Dörre sklasyfikował pracowników z podziałem na trzy sfery: integracji, oddzielenia i niepewności ${ }^{11}$. Do pierwszej należą zarówno zatrudnieni na stałe i na czas nieokreślony, jak również zatrudnieni w elastycznych formach. Pierwsi objęci są zabezpieczeniami społecznymi, drugim zaś ryzyko elastycznego zatrudnienia równoważy subiektywne poczucie zyskania wolności.

${ }^{10}$ Zob. U. Beck, Społeczeństwo ryzyka. W drodze do innej nowoczesności, tłum. S. Cieśla, Warszawa 2004.

${ }^{11}$ K. Dörre, Prekariat im Finanzmarkt-Kapitalismus, w: R. Castel, K. Dörre, Prekarität, Abstieg, Ausgrenzung. Die soziale Frage am Beginn des 21. Jahrhunderts, Campus, Frankfurt am Main - New York 2009, s. 48. 
Sfera oddzielenia gromadzi zarówno bezrobotnych poszukujących pracy, jak i długotrwale bezrobotnych młodych ludzi, którzy wykonują dorywcze prace $\mathrm{w}$ nieformalnej sieci społecznej: $\mathrm{w}$ rodzinie i sąsiedztwie. Większość bezrobotnych chce jednak znaleźć pracę $\mathrm{i}$ jest na to gotowa, nawet jeśli jest to jednoznaczne $\mathrm{z}$ zatrudnieniem, które nie zapewnia im dochodu wyższego od zasiłku i jest na niepewnych warunkach. Ostatnią sferę określił Dörre jako sferę niepewności. I właśnie tu zakwalifikowane zostały przez niego wszelkie odmiany prekariatu. Mamy tu do czynienia z różną strukturą społeczną, a co za tym idzie odmiennymi konsekwencjami, wynikającymi i rzutującymi zarazem na poszczególne biografie. To, co łączy pracowników zaliczanych do tej strefy, to pewne wspólne niezmienne cechy, przypisywane do atypowych form pracy, a które wymienione zostały już na samym początku.

Guy Standing wyróżnił natomiast siedem grup społecznych, które w XXI wieku funkcjonują obok siebie na rynku pracy. Pierwszą, najwęższą grupę stanowią elity, czyli nieliczni, ale za to najbogatsi ludzie globu. Dwie kolejne grupy - salariat i proficians - są równorzędne. Typowi przedstawiciele salariatu to przede wszystkim pracownicy umysłowi, urzędnicy, którzy pobierają stałą comiesięczną pensję. Tzw. proficians to z kolei ludzie, którzy dzięki swym umiejętnościom mogą uzyskiwać wysokie dochody z pracy kontraktowej lub na własny rachunek. Po dawnej klasie robotniczej (proletariacie) pozostali zaś obecnie pracownicy fizyczni (czwarta grupa). Trzy ostanie grupy stanowią ci, których sytuacja na rynku pracy jest najtrudniejsza, jeśli brać pod uwagę bezpieczeństwo i niepewność. Są to w kolejności: bezrobotni, osoby społecznie niedostosowane oraz prekariat ${ }^{12}$.

Niezależnie od liczby grup czy sfer, na które dzieli się uczestników działających na rynku pracy, ci którzy kwalifikują się jako prekariat, ogólnie stanowią grupę najsłabszych. To w nich najbardziej uderzyły skutki globalizacji, ich płace są niższe i ła-

${ }^{12}$ G. Standing, Prekariat. Nowa niebezpieczna klasa, tłum. K. Czarnecki i in., Warszawa 2014, s. 44-45. 
two ich zastąpić nowymi pracownikami. Przytoczone klasyfikacje wyraźnie wskazują też, że model stałego pełnoetatowego pracownika został zaanektowany przez inne sposoby organizacji pracy. Nie do końca prawdziwe jest przy tym przekonanie, że problem, o którym mowa, dotyczy wyłącznie osób o bardzo niskich dochodach, pracujących z konieczności na własny rachunek, pracowników czasowych, przewlekle chorych czy samotnych rodziców z niskimi dochodami. Zmienia się bowiem także bardzo wyraźnie sytuacja klasy średniej, dla której uregulowany stosunek do pracy, wzmocniony ubezpieczeniem społecznym, nie jest już tak oczywisty. „Widoczny obecnie regres klasy średniej nie spowoduje powrotu do realiów społeczno-politycznych z pierwszej połowy XX wieku, lecz przyniesie ze sobą zupełnie nowe wyzwania. Tak np. robotnicy, którzy wtedy mieli silną świadomość klasową - bazując na przeświadczeniu, że do nich należy przyszłość - awansowali do niższej warstwy klasy średniej (...). Natomiast ci, którzy obecnie wypadają z klasy średniej, nie tworzą nowego proletariatu, lecz zasilają kręgi prekariatu"13. W postprzemysłowym społeczeństwie prekariat nie jest zatem tym, czym proletariat był w społeczeństwie przemysłowym.

Guy Standing określa „mianem prekariatu (...) ludzi cierpiących na brak siedmiu rodzajów bezpieczeństwa związanych z pracą". Są to brak bezpieczeństwa na rynku pracy (stosowne możliwości pracy zarobkowej), bezpieczeństwa zatrudnienia (np. ochrona przed arbitralnym zatrudnieniem) i miejsca pracy (utrzymanie zatrudnienia, awans), bezpieczeństwo pracy (m.in. BHP), bezpieczeństwo reprodukcji umiejętności (np. szkolenie zawodowe), bezpieczeństwo reprezentacji (związki zawodowe) oraz bezpieczeństwo dochodu. To ostatnie to między innymi powszechne zabezpieczenie społeczne ${ }^{14}$. W tym sensie prekariusz nie kontroluje więc własnego czasu i życia. Ogólnie rzecz ujmując, proletariusz zyskiwał władzę nad własnym życiem i czas wolny dzięki stopnio-

${ }^{13}$ H. Münkler, Przeklęci pęknięci, „Forum” (2010) nr 43, s. 29.

${ }^{14}$ G. Standing, Prekariat. Nowa niebezpieczna klasa, dz. cyt., s. 49. 
wemu rozszerzaniu się idei obywatelstwa i zyskaniu na prawach społecznych, a prekariusz przechodził - mówiąc obrazowo - drogę odwrotną.

\section{Prekarne zajęcia}

Co wiemy o doświadczeniach tych, którzy na co dzień doświadczają niepewności w związku z pracą? Problem z prekariatem polega na tym, że nie jest to grupa jednorodna praktycznie pod żadnym względem. Prekariusze są zróżnicowani zarówno ekonomicznie, jak i politycznie oraz społecznie. Jak podkreśla Guy Standing, problem dotyczy większości z nas, „jeśli wydarzy się jakiś wypadek albo kryzys pozbawi nas poczucia bezpieczeństwa"15.

Najbardziej rozpowszechniony stereotyp, dotyczący tzw. typowego prekariusza, przedstawia go jako człowieka z niskim wykształceniem i kwalifikacjami, tudzież ich brakiem, w związku z czym zmuszonym godzić się na każde warunki zatrudnienia i płacy. Jest to jednak uproszczone postrzeganie zjawiska, choć pewnie pozwalające zachować dobre samopoczucie tym, którzy nie odpowiadają temu obrazowi. Tymczasem można wymienić tu wiele zawodów, które do niedawna jeszcze nie kojarzyły się - choćby z uwagi na posiadane właśnie kwalifikacje - z niepewnością.

Obok dziennikarzy, tzw. wolnych strzelców, są pracownicy tymczasowi, niekoniecznie bez wykształcenia i pewnych kwalifikacji, wieczni stażyści, przedsiębiorcy - pozorni, gdyż stojący na czele jednoosobowych firm. Tak działają na przykład - także w Polsce usługi, to znaczy w oparciu o pracę prekaryjną.

Myliłby się jednak ten, kto myślałby, że na pracy prekaryjnej opierają się jedynie prywatni przedsiębiorcy, wykorzystując sytuację poszczególnych ludzi. Weźmy nasze środowisko. Uczelnie

\footnotetext{
${ }^{15}$ G. Standing, Prekariat. Nowa niebezpieczna klasa, dz. cyt., s. 137.
} 
państwowe nie zatrudniają już „swoich” pracowników, wykonujących pewnie nie tak prestiżowe być może prace, ale ważne, by uczelnia mogła jednak funkcjonować - mam tu na myśli pracowników portierni, sprzątających itd. To wszystko wykonują dziś właśnie firmy zewnętrzne. Tzw. outsourcing pozwala obniżać koszty pracy przez pracodawcę, który nie musi dodatkowo brać na siebie odpowiedzialności za pracownika.

Osobną kategorię stanowią doktoranci, którzy uczestniczą $\mathrm{w}$ badaniach, a przede wszystkim prowadzą zajęcia na takich samych prawach jak etatowi pracownicy naukowo-dydaktyczny. Jednocześnie studiują, a zatem z punktu widzenia uczelni są traktowani jak studenci, nie podlegają zatem kodeksowi pracy. Tylko już te wybrane przykłady pokazują, jak zróżnicowana jest to grupa.

Oczywiście - co zauważa Standing - nie wszyscy wykonujący prekarne zajęcia to wyłącznie ofiary rynku pracy ${ }^{16}$. Jedni stają się prekariuszami z braku faktycznych innych możliwości, ale inni - przynajmniej w swoim odczuciu - mogą cenić sobie taki sposób wykonywania pracy, jako bardziej odpowiadający ich sytuacji życiowej. Nie muszą zatem odczuwać swojej sytuacji jako groźnej, choćby ze względu na wiek i odległą jeszcze perspektywę wieku dojrzałego, starości i wszystkiego, co się z tym wiąże. Łatwo jest jednak wpaść w pułapkę ubóstwa, zwłaszcza gdy rozwojowi cywilizacji towarzyszy - mówiąc za Baumanem - produkcja ludzi zbędnych, których przecież można tak łatwo i szybko zastąpić.

\section{Polityka społeczna wobec prywatyzacji pracy}

Problem prekariatu kieruje nas w stronę polityki społecznej, a ściślej rzecz ujmując, jej roli wobec zmian, jakie dotyczą pracy. Zagadnienie to jest ważne, gdyż dotyczy nowych nierówności, które wynikają ze wspomnianego braku bezpieczeństwa, a co za tym

\footnotetext{
${ }^{16}$ G. Standing, Prekariat. Nowa niebezpieczna klasa, dz. cyt., s. 53.
} 
idzie niepewności prekaryjnych pracowników. Ta niepewność dotyczy nie tylko chwili obecnej, ale stawia pod znakiem zapytania przyszłość takich pracowników.

Prekariat we wszystkich swoich odmianach (prekarny, prekariusz) jest - można by powiedzieć - sprzeczny z samą ideą polityki społecznej. O ile bowiem polityka społeczna in statu nascendi zakładała właśnie bezpieczeństwo, to wszystko, co wiąże się z prekariatem, jest tego właśnie przeciwieństwem.

Wiek XIX oraz do części wieku XX pod pewnymi względami czynił sytuację prostszą. Państwo opiekuńcze, które podjęło się realizacji polityki społecznej, było państwem narodowym, w którym tak jak na przykład w modelu niemieckim - korporatyzm pogłębiał solidaryzm narodowy, ale także go kreował. Z początkiem lat 90 . ubiegłego wieku to się skończyło. Mówiąc ogólnie, polityka społeczna miała zapewnić obywatelom pomyślność i dobrobyt. Osiągnąć miano to dzięki pełnemu zatrudnieniu $\mathrm{w}$ warunkach gospodarki rynkowej w połączeniu z postulowaną ideą obywatelstwa, które spełnia się w prawie do wytwarzania, ale i korzystania z majątku narodowego oraz współdecydowania o sprawach publicznych.

Kryzysy ekonomiczne, największe od wielu dekad, kolejne procesy globalizacyjne, a także zastosowanie neoliberalnych recept, które sprowadzały wszystko do prywatyzowania i deregulacji, a co znalazło swoje apogeum w tzw. turbokapitalizmie ${ }^{17}$, stworzyły między innymi prekariat, a w konsekwencji - prekarne zajęcia.

Dyskusja o prekariacie przenosi się tym samym na inną płaszczyznę. Prekarność bowiem to nic innego jak odmowa dostępu do podstawowych praw jednostki. Problem tkwi zasadniczo w tym, że jak zauważył Standing - „prekariat to pierwsza klasa ludzi pracujących, która zamiast z czasem zyskiwać prawa - traci je. Traci prawa obywatelskie, kulturowe, społeczne i gospodarcze, które inne klasy przed nim wywalczyły. Kulturowe, bo prekariusze

${ }^{17}$ Przez turbokapitalizm rozumiem taki system, który w pogoni za zyskiem wyzbył się wszelkich hamulców moralnych. 
nie przynależą do dominującej społeczności. Polityczne, bo nie czują się reprezentowani przez partie. Socjalne, bo nie mają dostępu do gwarantowanych przez państwo przywilejów. I gospodarcze, bo nie mogą wykonywać wyuczonego zawodu"18.

Prekariusz jest pozbawiony tego, co pracownik etatowy ma zagwarantowane w pakiecie. Szkolenia zawodowe, prawo do urlopu, choroba itp. - wszystko to obciąża kosztami pracownika prekarnego. A przecież wcale tak nie musi być. Ogólnie sam problem nie tkwi w elastycznych miejscach pracy, ale $\mathrm{w}$ nadużywaniu tej formy, jak się to dzieje na przykład w Polsce. Elastyczność miała być alternatywą dla tych, którzy borykali się z trudnościami albo z wejściem na rynek pracy (młodzież), albo z ponownym zatrudnieniem po czasowej dezaktywacji zawodowej (np. kobiety po urlopach macierzyńskich). Tymczasem w Polsce właśnie rozumienie elastyczności poszło $\mathrm{w}$ odmiennym od zamierzonego kierunku, przyczyniając się do powiększenia prekarnych miejsc pracy. Polska, by odwołać się do statystyki, jest na 3. miejscu w Europie (za wielką Brytanią i Niemcami), jeśli chodzi o liczbę agencji pracy tymczasowej. Z danych, jakie prezentuje Krajowy Rejestr Agencji Zatrudnienia, wynika, że na początku stycznia 2016 roku było takich agencji dokładnie $6079^{19}$. To, co miało stać się ułatwieniem dla niektórych, stało się niemal normą.

I tu polityka społeczna w pewnym sensie sprzeniewierzyła się swojej klasycznej roli, która polega na dążeniu do spójności społecznej. Trudno bowiem o spójność, jeśli prekariat traktujemy jako niejednorodną grupę pracowników, o różnym poziomie wykształcenia, kwalifikacji i wykonywanego zawodu. Nie łączy ich

${ }^{18} \mathrm{G}$. Standing, Nowa niebezpieczna klasa sięgnie po władzę? (wywiad A. Rybińskiej), „Nowa Konfederacja”, 4.03 .2015 r., https:/ / nowakonfederacja. pl/nowa-niebezpieczna-klasa-siegnie-po-wladze/ (10.05.2017).

${ }^{19}$ Dane podaję za Krajowym Rejestrem Agencji Zatrudnienia. Por. www. stor.praca.gov.pl/portal/\#/kraz/statystyki (19.08.2017). Najnowsze dane z sierpnia 2017 r. to 8407 . W 2013 r. pracodawcy mogli korzystać z 4540 agencji, a już rok później liczba ta wzrosła do 5516. Widać zatem szybki przyrost agencji zatrudniających pracowników tymczasowych. 
wspólnota interesów ani politycznych, ani ekonomicznych. W tym sensie prekariat nie zastępuje proletariatu, który już dawno zniknął z porządku społeczno-politycznego. Trudno też mówić o spójności, gdy nie są zaspokajane potrzeby obywateli przez gwarancję bezpieczeństwa społecznego, jaką daje praca, a nie zasiłki. Praca bowiem pełni w życiu człowieka o wiele bardziej złożoną rolę niż samo zarabianie pieniędzy, choć oczywiście niewielu będzie negować ten końcowy efekt działalności człowieka.

\section{Konkluzja}

Zmieniło się to, co dla paru pokoleń stanowiło aksjomat pewność pracy. Nieprawdziwe jest przy tym przekonanie, że dotyczy to wyłącznie osób z niskim wykształceniem i kwalifikacjami lub ich brakiem, samotnych matek, niepełnosprawnych itd. Każdy może stać się prekariuszem. Naturalnie inaczej może to wyglądać, jeśli uwzględni się indywidualne biografie. Jednak wyraźnie zmienia się także sytuacja klasy średniej, dla której uregulowany stosunek do pracy wzmocniony ubezpieczeniem społecznym był do niedawna jeszcze czymś tak oczywistym.

Praca określa człowieka - wyznacza bowiem poziom naszych zarobków, stanowi o jego możliwościach życiowych, uściśla środowisko, w którym przebywamy, i sposób życia, jaki prowadzimy. Problem prekariatu, przed którym staje obecnie wiele krajów, dotyczy sposobu, w jaki można by zwiększyć poczucie bezpieczeństwa socjalnego zatrudnionych i ich rodzin. Bardziej podstawowe pytanie polega jednak na tym, czy polityka społeczna ma w ogóle odpowiednie narzędzia, by tę sytuację nie tyle zmienić, ile załagodzić jej negatywne skutki.

Wnioski, jakie można tu wyprowadzić, są następujące. Po pierwsze, prekariat we wszelkich jego odmianach to problem systemowy, który został wygenerowany przez rynek. Z konsekwen- 
cjami zaś ma poradzić sobie polityka społeczna. Po drugie, polityka społeczna nie jest jednak w stanie na poziomie krajowym rozwiązywać problemy, które są wynikiem globalnych procesów.

Czy istnieje zatem wyjście z tej sytuacji? Na płaszczyźnie praktycznej zapewne problem prekariatu, będący nową formą nierówności społecznych, będzie wymagał stworzenia rozwiązań na poziomie międzynarodowym, np. prawnych, które by ucywilizowały działania wielkich ponadnarodowych korporacji. To już się dzieje. W warstwie ideologicznej zaś ponownego przedyskutowania podstawowych praw jednostki. I z tym jest znacznie trudniej.

\section{Bibliografia}

Bauman Z., Życie na przemiał, tłum. T. Kunz, Kraków 2004.

Beck U., Społeczeństwo ryzyka. W drodze do innej nowoczesności, tłum. S. Cieśla, Warszawa 2004.

Bourdieu P., Prekarität ist überall, w: Gegenfeuer. Wortmeldungen im Dienste des Widerstandes gegen die neoliberale Invasion, hrsg. A. Pfeuffer, UVK, Konstanz 1998.

Castel R., Die Metamorphosen der sozialen Frage. Eine Chronik der Lohnarbeit, UVK Verlagsgesellschaft mbH, Konstanz 2000.

Castel R., Dörre K., Prekarität, Abstieg, Ausgrenzung. Die soziale Frage am Beginn des 21. Jahrhunderts. Campus, Frankfurt am Main - New York 2009.

Dörre K., Prekariat im Finanzmarkt-Kapitalismus, w: R. Castel, K. Dörre, Prekarität, Abstieg, Ausgrenzung. Die soziale Frage am Beginn des 21. Jahrhunderts, Campus, Frankfurt am Main - New York 2009.

Krajowy Rejestr Agencji Zatrudnienia, www.stor.praca.gov. pl/portal/\#/ kraz/statystyki (19.08.2017).

Martin H.-P., Schumann H., Pułapka globalizacji. Atak na demokrację i dobrobyt, tłum. M. Zubyra, Wrocław 1999. 
Münkler H., Przeklęci pęknięci, „Forum” (2010) nr 43.

Riffkin J., Schyłek sity roboczej na świecie i początek ery postrynkowej, tłum. E. Kania, Wrocław 2003.

Standing G, Nowa niebezpieczna klasa sięgnie po władze? (wywiad A. Rybińskiej), „Nowa Konfederacja”, 4.03.2015 r., https://nowakonfederacja.pl/nowa-niebezpieczna-klasa-siegnie-po-wladze/ (10.05.2017).

Standing G., Prekariat. Nowa niebezpieczna klasa, tłum. K. Czarnecki i in., Warszawa 2014. 
A/4* Uniwersytet Papieski

Iflat. Jana Pawla II 